\title{
Ten years experience of aortic valve replacement with aortic homograft root replacement
}

\author{
Dezanos de experiência com a substituição da valva aórtica com homoenxertos valvares aórticos implantados \\ pela técnica da substituição total da raiz.
}

Francisco COSTA $^{1}$, Daniele de Fátima FORNAZARI ${ }^{2}$, Camila Naomi MATSUDA ${ }^{2}$, Rafael de Almeida TORRES ${ }^{2}$, Evandro SARDETTO ${ }^{3}$, Andreia Dumsch de Aragon FERREIRA ${ }^{3}$, Claudinei COLATUSSO ${ }^{4}$, Carlos Henrique Gori GOMES $^{4}$, Marise Brenner Affonso da COSTA ${ }^{5}$

RBCCV 44205-811

\begin{abstract}
Objective: To evaluate the immediate and late results of 10 years of aortic valve root replacement with aortic homografts and to identify possible risk factors related with homograft primary tissue failure.

Methods: Between May 1995 and January 2006, 282 patients with a mean age of $\mathbf{5 2 . 8} \pm \mathbf{1 6 . 6}$ years were submitted to aortic valve root replacement with aortic homografts. The most prevalent etiologies were calcified bicuspid aortic valves and senile degeneration, corresponding to $49 \%$ of the cases. Forty-seven patients were reoperations and acute bacterial endocarditis was present in 26. Associated procedures were necessary in $\mathbf{1 1 3}$ patients. The homograft was implanted as a root replacement in all. Follow-up time varied between 1 and 129 months (mean $=\mathbf{4 1} \pm \mathbf{2 5}$ months).

Results: Early overall mortality was $7 \%$, with only $2.6 \%$ for cases of elective aortic valve replacement in isolation. Of the 262 patients discharged from hospital, it was possible to obtain clinical and echocardiographic evaluations of 209. Fifty-one patients $(\mathbf{2 0} \%)$ were lost in the follow-up. There were 17 late deaths between the the $2 \mathrm{nd}$ and 81 st postoperative months, which resulted in an actuarial survival rate of $90 \%$ and $80.1 \%$ at 5 and 10 years respectively. There were eight
\end{abstract}

1. Professor of the Medicine Department - PUCPR. Cardiovascular surgeon

2. Medicine student - PUCPR

3. Master in Surgery, Surgeon Santa Casa de Curitiba - PUCPR.

4. Resident in Cardiovascular surgery

5. Master in Health Sciences. Coordinator of the Human Heart Valve Bank of Santa Casa de Curitiba

Work carried out in Santa Casa de Curitiba, PR.

Correspondence address:

Francisco Diniz Affonso da Costa. Rua Henrique Coelho Neto, 55. Curitiba, PR. CEP 82200-120.

E-mail: fcosta@mps.com.br thromboembolic events (four early and four late), for a linearized incidence of $0.3 \%$ events/100 patients/year. Bacterial endocarditis occurred on three occasions $(0.4 \% / 100$ patients/ year). Nine patients were re-operated, of which only three were related to the homograft (one case of primary tissue failure and two of bacterial endocarditis), corresponding to a probability of $94 \%$ of the patients free from this complication at 10 years of follow-up. Late echocardiographic analysis demonstrated maximum gradients varying between 3 and $47 \mathrm{mmHg}$ (mean $=14.5 \mathrm{mmHg}$ ), with only two patients having a maximum gradient greater than $40 \mathrm{mmHg}$. Moderate valvar insufficiency was present in four cases.

Conclusions: The early and late results of aortic valve root replacement with aortic valve homografts were excellent, with a good functional recovery and low late morbimortality. The only risk factor for primary tissue failure was age below 20 years at the time of the operation. Aortic homografts are an excellent option for over 40 -year-old patients, especially for those who have contraindications or do not warrant anticoagulation

Descriptors: Aortic valve, surgery. Prostheses and implants. Transplantation, homologous. 


\section{Resumo}

Objetivo: Avaliar os resultados imediatos e tardios de 10 anos da substituição da valva aórtica por homoenxertos valvares aórticos implantados pela técnica de substituição total da raiz, e identificar eventuais fatores de risco correlacionados com a degeneração tecidual primária dos enxertos.

Método: Entre maio/1995 e janeiro/2006, 282 pacientes com média de idade de $\mathbf{5 2 , 8} \pm \mathbf{1 6 , 6}$ anos foram submetidos à substituição da valva aórtica com homoenxertos valvares. As etiologias prevalentes foram a valva aórtica bicúspide calcificada e a degeneração senil em $\mathbf{4 9 \%}$ dos casos. Quarenta e sete pacientes eram reoperações e 26 tinham endocardite bacteriana aguda. Procedimentos associados foram realizados em 113 pacientes. $O$ homoenxerto valvar foi implantado pela técnica de substituição total da raiz em todos os casos. O tempo de seguimento pós-operatório variou de 1 a 129 meses (média $=41 \pm 25$ meses).

Resultados: A mortalidade imediata foi de 7\%, sendo de apenas $2,6 \%$ nos casos de operação eletiva para a substituição isolada da valva aórtica. Dos 262 que receberam alta hospitalar, foi possível obter avaliação clínica e/ou ecocardiograma em 209 deles, sendo $51(20 \%)$ perdidos durante o seguimento. Houve 17 óbitos tardios, entre o $2^{\circ}$ e $81^{\circ}$ meses de pós-operatório, o que resultou em curva atuarial de sobrevida global de $90 \%$ e $80,1 \%$ aos 5 e 10 anos de evolução, respectivamente. Foram observados apenas oito episódios tromboembólicos (quatro imediatos e quatro tardios), durante a evolução para uma

\section{INTRODUCTION}

The use of homografts for aortic valve replacement presents advantages in relation to other valve substitutes, including an improvement in the hemodynamic performance, which provides a greater regression of the left ventricular mass in the postoperative period, lower incidences of thromboembolic phenomena without anticoagulation therapy and a higher resistance to infections. Thus it is considered to be the favored graft for the surgical treatment of bacterial endocarditis. Despite of this, some limitations such as unsatisfactory durability for under 20-year-old patients, the complexity of the operative technique and the limited supply of grafts has made its routine use limited to a few centers $[1,2]$.

The long-term results (over 20 years) of aortic valve homografts reflect the experience with the use of "fresh" valves preserved in nutrient solutions with antibiotics and orthotopically implanted in the subcoronary position $[2,3]$.

However, improvements in tissue preservation and in graft techniques were recently introduced to try to improve the outcomes. Thus, the implant of cryopreserved homografts by the aortic root replacement technique with reimplantation of coronary arteries is currently the commonest incidência linearizada de $0,3 \% / 100$ pacientes/ano. Endocardite bacteriana ocorreu em três ocasiões $(0,4 \% / 100$ pacientes/ano). Nove pacientes foram reoperados, dos quais apenas três por problemas no homoenxerto (uma degeneração tecidual e dois casos de endocardite), o que resultou numa probabilidade de $\mathbf{9 4 \%}$ livres dessa complicação aos 10 anos de seguimento. A análise do ecocardiograma tardio demonstrou gradiente máximo variando entre 3 a $47 \mathrm{mmHg}$ (média de 14,5 $\mathrm{mmHg}$ ), sendo que apenas dois pacientes apresentavam gradiente superior a $40 \mathrm{mmHg}$. Insuficiência valvar moderada foi encontrada em quatro pacientes.

Conclusões: Os resultados imediatos e tardios com a substituição da valva aórtica por homoenxerto valvar criopreservado foram excelentes, com boa capacidade funcional e baixa morbi-mortalidade tardia. $O$ único fator de risco para a degeneração tecidual primária foi a idade do paciente menor que 20 anos. Homoenxertos aórticos representam uma excelente opção para pacientes com idade acima de 40-50 anos, especialmente naqueles com contra-indicação ou que não desejem fazer o uso de anticoagulantes.

Descritores: Valva aórtica, cirurgia. Próteses e implantes. Transplante homólogo.

technique employed $[1,4]$.

Although some studies suggest that these modifications are associated with better clinical results and longerlasting grafts, it is still a controversial issue without definitive conclusions $[1,2,4]$. Additionally, the majority of cryopreserved aortic homograft series implanted by complete aortic root replacement is small, with a limited follow-up period, especially for cases with more than 10 years of evolution $[1,5,6]$.

Our experience with aortic homograft valve replacement was initiated in 1995, mainly with cryopreserved aortic homografts and using the aortic root replacement technique. During that period, our institution considered valve homografts as the favored valve substitute for the majority of over 40-year-old patients even in the presence of associated conditions, advanced ages and reduced cardiac function. The aim of this study was to assess the immediate and longterm clinical outcomes of this operation and to identify risk factors related to primary structural dysfunction of aortic homografts.

\section{METHOD}

\section{Patients}

Two hundred and eighty two patients from the Heart 
Surgery Service of Aliança Saúde Santa Casa - PUCPR and from Pequeno Príncipe Children's Hospital underwent aortic valve replacement with aortic homograft root replacement from May 1995 to January 2006. The ages of patients ranged from 5 to 88 years (mean= $52.8 \pm 16.6$ years) with 19 under 20-year-old patients and 187 male patients $(66 \%)$.

The most frequent etiologies were calcification of the bicuspid valve and senile atherosclerotic degeneration corresponding to $49 \%$ of the cases. Forty-seven patients had already been submitted to surgeries of the aortic valve and 26 had active acute bacterial endocarditis at the time of the surgery. One hundred and thirteen patients (39\%) had other associated heart conditions requiring concomitant procedures including coronary artery bypass grafting, correction of ascending aorta aneurysms and mitral valve replacement and/or repair. Some clinical data and complementary examinations of the patients are illustrated in Tables 1 and 2.

Table 1. Clinical data in 282 patients submitted to the implant of aortic valve homografts

\begin{tabular}{|c|c|c|c|}
\hline Data & Mean \pm SD & $\mathrm{n}$ & $\%$ \\
\hline Age & $52.8 \pm 16.6$ years & & \\
\hline$<20$ years & & 19 & $(6.8)$ \\
\hline 21 to 40 years & & 36 & $(12.8)$ \\
\hline 41 to 60 years & & 117 & $(41.4)$ \\
\hline$>60$ years & & 110 & $(39.0)$ \\
\hline \multicolumn{4}{|l|}{ Gender } \\
\hline Male & & 187 & $(66.3)$ \\
\hline Female & & 95 & $(33.6)$ \\
\hline \multicolumn{4}{|l|}{ Ethnic group } \\
\hline White & & 249 & $(88.2)$ \\
\hline Black & & 8 & $(2.8)$ \\
\hline Mixed & & 22 & $(7.8)$ \\
\hline Asian & & 3 & $(1.2)$ \\
\hline \multicolumn{4}{|l|}{ Functional Class } \\
\hline I & & 30 & $(75.0)$ \\
\hline II & & 104 & (16.3) \\
\hline III & & 115 & $(7.0)$ \\
\hline IV & & 34 & (1.7) \\
\hline \multicolumn{4}{|l|}{ Ejection fraction } \\
\hline$>50 \%$ & & 205 & $(72.6)$ \\
\hline $35-50 \%$ & & 39 & (13.8) \\
\hline$<35 \%$ & & 38 & $(13.6)$ \\
\hline
\end{tabular}

Legend: $n$ - number; \% - percentage; SD - standard deviation.
Table 2. Operative findings of 282 patients submitted to the implant of aortic valve homografts

\begin{tabular}{|c|c|c|}
\hline Data & $\mathrm{n}$ & $\%$ \\
\hline \multicolumn{3}{|l|}{ Valve lesion } \\
\hline AoS & 108 & $(38.4)$ \\
\hline AoI & 101 & $(35.8)$ \\
\hline DaoL & 73 & $(25.8)$ \\
\hline \multicolumn{3}{|l|}{ Etiology } \\
\hline Bicuspid valve calcification & 117 & $(41.4)$ \\
\hline Aging degeneration/calcification & 22 & $(7.8)$ \\
\hline Degenerative & 18 & $(6.3)$ \\
\hline Rheumatic disease & 50 & $(17.7)$ \\
\hline Congenital & 13 & $(4.6)$ \\
\hline Prosthesis dysfunction & $43 *$ & $(15.2)$ \\
\hline Bacterial endocarditis & 26 & $(9.2)$ \\
\hline Marfan’s syndrome & 5 & $(1.7)$ \\
\hline \multicolumn{3}{|l|}{ Associated procedures } \\
\hline Mitral Plasty/Prosthesis & 34 & $(12.0)$ \\
\hline Correction of Asc Ao/Arch Aneurysm & 31 & $(11.0)$ \\
\hline Coronary artery bypass grafting & 46 & $(16.3)$ \\
\hline Correction of the Congenital Heart disease & 2 & $(0.7)$ \\
\hline \multicolumn{3}{|l|}{ Operation } \\
\hline Primary & 235 & $(83.3)$ \\
\hline Reoperation & 47 & $(16.7)$ \\
\hline
\end{tabular}

Legend: AoS - Aortic Stenosis. AoI - Aortic Insufficiency. DAoL - Double Aortic Lesion. $n$ - number. \% - percentage. (*) 12 cases of prosthesis dysfunction with acute bacterial endocarditis

Valve homografts

All homografts used in the study were from the Human Heart Valve Bank of Santa Casa de Curitiba. Two hundred and seventy two were cryopreserved, two were fresh and eight were decellularized.

The details of the procurement, processing, storage and distribution of the grafts have been described previously [7]. The grafts were decontaminated in a RPMI 1640 nutrient solution, with low antibiotic concentration (240 $\mu \mathrm{g} / \mathrm{mL}$ of cefoxitin, $120 \mu \mathrm{g} / \mathrm{mL}$ of lincomycin, $50 \mu \mathrm{g} / \mathrm{mL}$ of vancomycin and $100 \mu \mathrm{g} / \mathrm{mL}$ of polymyxin B) for $24-48$ hours at $4{ }^{\circ} \mathrm{C}$. The fresh homografts were maintained in this solution for a maximum of four weeks.

For cryopreserved homografts, the freezing process was made in a RPMI 1640 solution, 10\% dimethyl sulphoxide and $10 \%$ of fetal bovine serum in cryopreservation equipment (Planer, model KRIO 10-16 Series III and temperature controller model K10-12, Sunbury-on-Thames, 
UK) with tissue freezing at a speed of $-1{ }^{\circ} \mathrm{C} / \mathrm{min}$ until the temperature was $-80^{\circ} \mathrm{C}$. At the end of the freezing process, the grafts were transferred to storage freezers (Sanyo, model ultra-low temperature freezer $-152^{\circ} \mathrm{C}$ - MDF-1155ATN or Custom Biogenic Systems, model storage unit S-1500 B, Osaka-Japan) at a temperature of liquid nitrogen vapor $\left(-150^{\circ} \mathrm{C}\right)$.

During the operation, the grafts were thawed rapidly using saline solution at temperatures ranging from 42 to $50{ }^{\circ} \mathrm{C}$, followed by gradual dilution of the cryoprotector solution with RPMI 1640 and 10\% fetal bovine serum.

A decellularized solution based on $1 \%$ deoxycholic acid, $1 \%$ sodium dodecyl sulfate and $70 \%$ ethanol was employed for the decellularized homografts. The mean diameter of the homografts was $21.4 \mathrm{~mm}$ (range from 14 to $27 \mathrm{~mm}$ ) and the age of the donors ranged from 6 to 56 years (mean $=36.7 \pm 14.2$ years).

\section{Preoperative evaluation}

All patients were evaluated in the preoperative period by physical examinations, electrocardiography, chest radiographies from postero-anterior and side views and bidimensional Doppler echocardiogram.

Using echocardiography, the left ventricle systolic and diastolic dimensions (SDLV and DDLV), thickness of the left ventricle posterior and septal walls (PW and Septum), left ventricle percentage shortening and ejection fraction $(\%$ $\triangle \mathrm{D}$ and $\mathrm{EF}$ ) and the right ventricle diastolic dimension were evaluated. The mass and the index of the left ventricle (VM and IVM) were also calculated. The mean and instantaneous maximum gradients ( $\Delta \mathrm{pm}$ e $\Delta$ pmax $)$ through the aortic valve were estimated by Doppler in cases of stenosis and double aortic lesion. Valvar insufficiency was identified as absent, insignificant, slight, moderate or significant [8]. Coronary cineangiography was routinely performed for over 40 -yearold patients.

\section{Operative technique}

The operations were performed by medial esternotomy using cardiopulmonary bypass and cannulation of the aorta and the right atrium. In mitral valve patients, the cava venae were cannulated separately. Moderate systemic hypothermia $\left(32^{\circ} \mathrm{C}\right)$ was employed and myocardial protection was achieved with a continuous cold cardioplegic sanguineous solution $\left(4-8^{\circ} \mathrm{C}\right)$ direct to the coronary ostia. The aortic cross-clamping time averaged $76 \pm 21$ minutes (range 43 to 128 minutes) and cardiopulmonary bypass time averaged $91 \pm 29$ minutes (range 50 to 154 minutes).

Aortic root replacement was accomplished by transverse sectioning of the ascending aorta above the sinotubular junction and the proximal portion of the aorta, including the valve, was desiccated leaving behind only two stumps on the aortic wall with coronary orifices. Decalcification of the aortic ring was aggressive and when necessary, all calcified tissue was desiccated including tissue that extended to the anterior cuspid of the mitral valve or that invaded the interventricular septum. The homografts were anastomosed proximately to the aortic ring in an intra-annular position, with single polyester 4-0 sutures and distally, to the ascending aorta, with a continuous polypropylene 4-0 suture. The coronary stumps were re-implanted in the end-side portion at the corresponding Valsalva sinus using

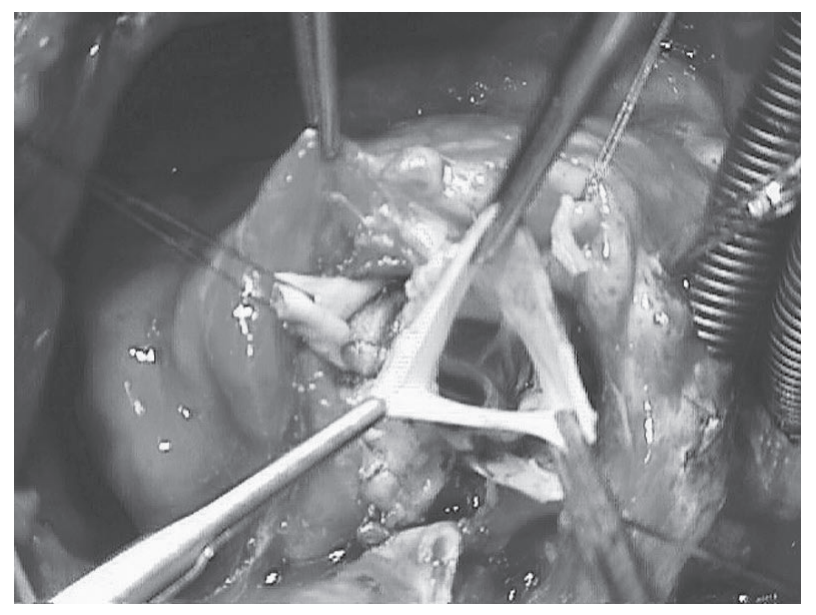

Fig. 1-Operative aspect of the aortic homograft implant by aortic root replacement

continuous propylene 5-0 or 6-0 sutures (Figure 1).

In cases of aortic ring dilation, diameter reduction was performed with single polyester 4-0 sutures anchored externally to Teflon or bovine pericardium strips, to make the diameter of the root compatible to the available homograft. In cases of ascending aorta dilation, an aortoplasty was carried out distally. In patients with aneurysms, the ascending aorta was substituted using a homograft tube when it was long or with the insertion of a Dacron tube, when necessary.

Coronary artery bypass grafting, mitral repairs or prosthesis implants were performed in patients with associated lesions, according to standard techniques at our center.

\section{Post operative evaluation}

\section{In the hospital}

The immediate postoperative evaluation included an analysis of hospital complications, cardiac auscultation and a pre-discharge electrocardiogram. 
All patients underwent bidimensional Doppler echocardiography before hospital release. The preoperative examinations relating to the heart cavities and ventricle function, were repeated. Additionally, the mean and instantaneous maximum gradients through valvar homografts were measured, as was possible reflux [8].

\section{Late postoperative period}

During 2005, three medicine students were selected to contact all patients who were released from hospital.

The patients were requested to return every six months after the operation, when they were submitted to new physical evaluations and a control bidimensional echocardiogram. The postoperative complications were analyzed according to established guidelines [9]. For the patients that could not return for the evaluation, the clinical information and echocardiographic features were obtained by telephone from the patient or physician. The followup period ranged from 1 to 129 months (mean $=41 \pm 25$ months).

\section{Statistical analysis}

The determination of survival curves and late complications was achieved using the Kaplan-Meier method with a $95 \%$ confidence interval.

The linear incidences of the events were assessed with Prism Statistics software for Macintosh.

\section{RESULTS}

The overall hospital mortality was $7 \%(20 / 282)$. With stratification of the patients in subgroups, a mortality of $13 \%(6 / 46)$ was observed for those with associated CABG, $17 \%(6 / 34)$ for mitral-aortic patients and 34\% (9/26) for cases of single or multiple valve bacterial endocarditis. The mortality for elective operations of aortic valve replacement was only $2.6 \%(4 / 152)$. The cause of immediate death were low output syndrome (nine cases), hemorrhage (four cases), mesenteric thrombosis, sepsis and strokes (two cases each) and irreversible ventricular fibrillation (one case).

Of the 282 patients who were discharged, it was impossible to contact $51(20 \%)$ during the follow-up. Clinical data and complementary examinations were obtained for the remaining 209 cases. There were 17 late deaths between the $2^{\text {nd }}$ and the $81^{\text {st }}$ months of the postoperative period, which resulted in overall actuarial survival curves of $90 \%$ and $80.1 \%$ at 5 and 10 years, respectively (Figure 2). Among the late deaths, seven were not caused by heart problems. From the 10 patients who died because of heart problems, only two deaths were related to the prostheses due to reoperations because of bacterial endocarditis (Table 3 ).

The actuarial survival curves were stratified by age and associated procedures are shown in Figures 3 and 4.

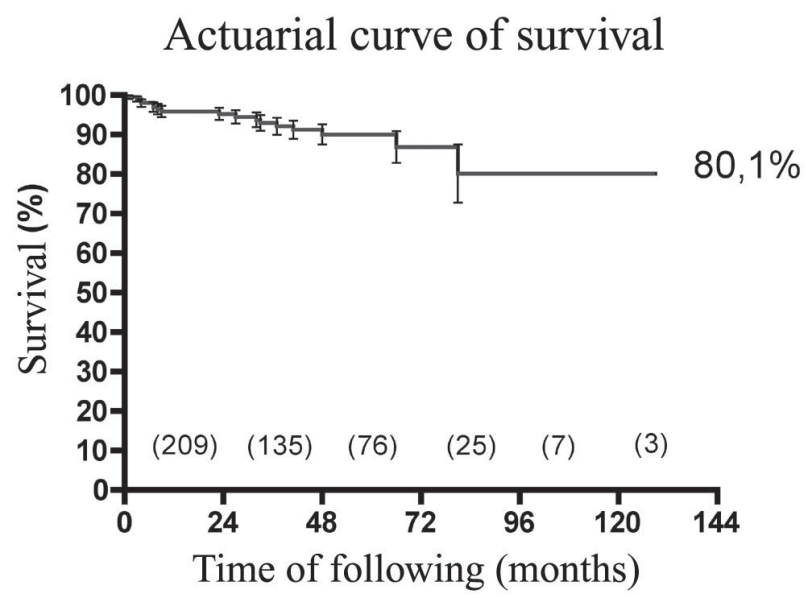

Fig. 2 - Actuarial curve of survival in 282 patients submitted to aortic valve replacement using a homograft

Table 3. Cause of late deaths

\begin{tabular}{lc}
\hline Cause & Number \\
\hline Non Cardiac & 7 \\
CVA & 2 \\
Mesenteric thrombosis & 1 \\
Intestine cancer & 1 \\
Sepsis & 1 \\
Bone marrow cancer & 1 \\
Lung cancer & 1 \\
& \\
Cardiac & 10 \\
Acute myocardial infarction & 3 \\
Congestive heart failure & 2 \\
Sudden death & 3 \\
Homograft Reoperation & 2 \\
\hline
\end{tabular}

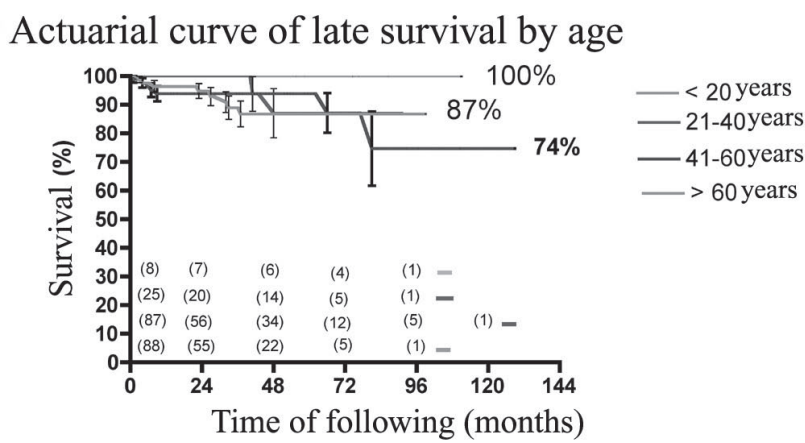

Fig. 3-Actuarial curve of survival stratified by age of 282 patients submitted to aortic valve replacement using a homograft 
Actuarial curve of late survival (associated procedures)

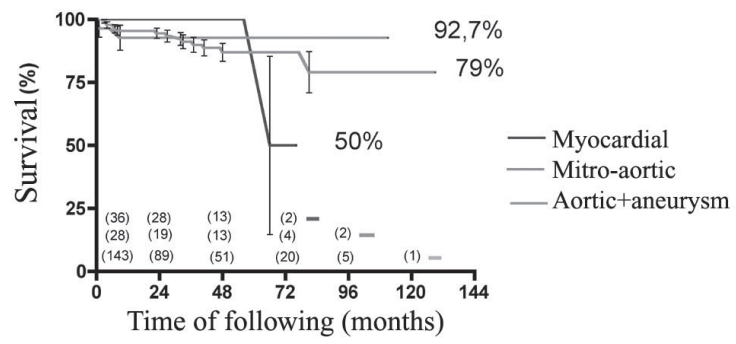

Fig. 4 - Actuarial curve of survival stratified by associated procedures in 282 patients submitted to aortic valve replacement using a homograft

There was a significant improvement of symptoms in the majority of patients: $142(75 \%)$ are in NYHA functional class I, 31 (18\%) are in functional class II and only $15(7 \%)$ patients are considered functional class III.

The incidence of thromboembolism was low with four cases of brain embolia in the immediate postoperative period and another four late events, also of the central nervous system resulting in a linear incidence of $0.3 \%$ events/100 patients/year. Strokes were the cause of two immediate deaths and left one patient with sequels. Of the late events, strokes were fatal in two patients and transient without sequels in another two. The incidence of patients without thromboembolism was 97.2 and $89.5 \%$ at 5 and 10 years, respectively. All patients who presented with strokes were over 65 years old, with one exception, a 50-year-old patient.

Bacterial endocarditis occurred in three cases giving a linear incidence of 0.4 events/100 patients/year. Results show that patients have a $97 \%$ probability of not presenting with bacterial endocarditis after the $10^{\text {th }}$ year of evolution. Two patients with endocarditis were reoperated and died during the surgery and another one had a good recovery on only clinical management.

There were nine reoperations in the follow up period. Three patients were submitted to CABG between the $3^{\text {rd }}$ and $111^{\text {th }}$ postoperative months. In the two earliest cases, the causes were iatrogenic lesions due to the handling of the coronary ostia that resulted in intimal hyperplasia with a significant stenosis of the left coronary artery trunk. The third patient presented with coronary atherosclerotic disease and was revascularized in the $10^{\text {th }}$ postoperative year. The homograft of this patient was still functioning normally. Three patients were reoperated due to dysfunction of mitral valve repair, which occurred because of progressive fibrosis, leading to stenosis in two cases and annular dilation in the other. In the first two patients, implantation of mitral valve prostheses was necessary while in the other only a new repair was sufficient. In only three cases replacement of the valvar homograft was necessary. Two patients presented with bacterial endocarditis that was not responsive to antibiotics. They were reoperated in the acute phase and did not survive. A 13-year-old presented with stenosis due to

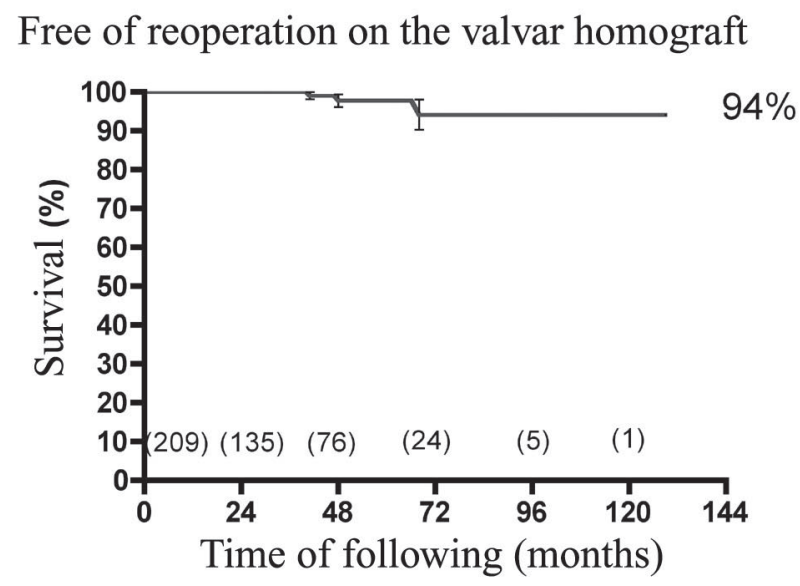

Fig. 5 - Probability of homograft reoperation in 282 patients submitted to aortic valve replacement using a homograft

calcification and the homograft was successfully substituted. The actuarial curve of patients free from reoperation shows that $94 \%$ of the patients will not present this complication within the first 10 postoperative years giving a linear incidence of 0.1 events/100 patients/year (Figure 5).

Two children ( 7 and 12 years old) presented with maximum instantaneous gradients of more than $40 \mathrm{mmHg}$ in the last echocardiogram and another four patients showed moderate aortic insufficiency and were regarded as having primary structural dysfunction. Thus, the possibility of patients being free from reoperations and having normal functioning homografts was 93.8 and $90.2 \%$ at 5 and

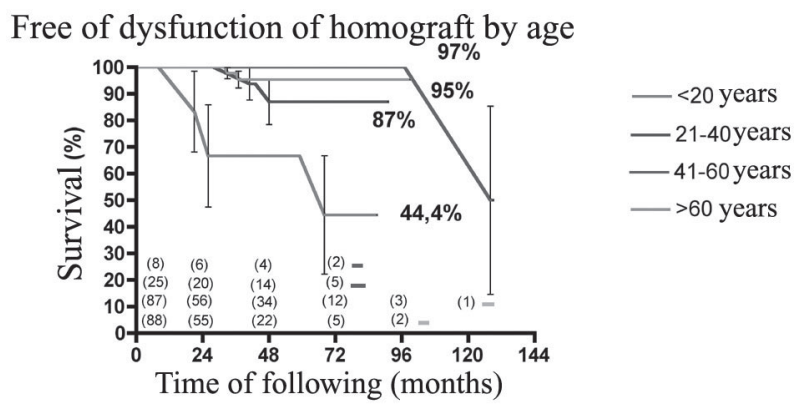

Fig. 6 - Probability of homograft reoperation and/or dysfunction stratified by age of 282 patients submitted to aortic valve replacement using a homograft 
10 postoperative years, respectively. When the patients were stratified by age, the probability of being free from reoperation or to have a homograft dysfunction ranged from $44.4 \%$ in under 20 -year-old patients to $95.3 \%$ in over 60 -year-old patients (Figure 6).

Table 4 presents the echocardiographic data of the preoperative, immediate postoperative and late postoperative periods. The data show good immediate and late hemodynamic performance of the homografts, with the maintenance of low gradients and valve competence. Additionally, there was an improvement of the contractile function and a significant reduction in the left ventricular mass of the majority of patients.

\section{DISCUSSION}

Different to other studies, in which aortic valve homografts were selectively employed in patients with specific indications $[1,3,5]$, our series represents a strategy of their preferential use to replace the aortic valve in adults independently of factors such as advanced age, functional class, left ventricle function or the concomitant presence of coronary insufficiency, mitral valve disease or ascending aorta aneurysms. Over the ten years of this study, aortic valve homografts were not considered the first choice for replacement for only under 50-year-old patients (in these cases the Ross operation was preferred), in patients who required simultaneous implantation of a conventional valve prosthesis in the mitral valve position, when no adequate homograft was available during the surgery or if patients chose a mechanical valve prosthesis [10].

The routine use of valvar homografts was only possible due to the great availability of grafts provided by the Human Heart Valve Bank in our institution. In the first five years of the study availability was higher than demand but, as other centers started to use the service, limitations have become more frequent, especially for aortic valves with diameters greater than 23-24 mm. The scarcity of homologous aortic valves is common in many centers that use homografts and this may be the most important limitation for their use. As a result, several researchers recommend that their use should be restricted to patients that would have better results, such as infectious endocarditis cases, women in child-bearing ages, cases in which anticoagulants are totally contraindicated, athletes that need a prosthesis with excellent hemodynamic performance or patients with a small aortic ring $[1,7,11]$.

Besides the technical complexity, our results demonstrate that the systematic application of aortic valve homografts can be achieved with low immediate mortality in comparison to conventional valve prostheses $[1,2]$. Our overall mortality of $7 \%$ reflects the complexity and heterogeneity of the cases included in this study. In patients submitted to valve replacement in isolation, including cases of reoperation, the mortality was only $2.6 \%$. These results are comparable to the results of the study by Pomerantzeff et al. [12], in which the mortality rate was 4.7 and $12.8 \%$ for aortic and mitral-aortic patients with Fisics-Incor prostheses, or the study by Bacco et al. [13], in which the immediate overall mortality was $11 \%$, after aortic valve replacement using St Jude MedicalBiocor prostheses. In a metanalysis of publications on patients submitted to aortic valve replacement with homografts, Takkenberg et al. $[4,5]$ reported immediate mortality rates that ranged from $2 \%$ to $19 \%$. These percentages probably reflect the different indications of several surgical groups. Nonetheless, the determination of the surgical group and technical improvements are fundamental to the operative result according to O'Brien et al. [1], who had a mortality rate of $1.1 \%$ in 352 consecutive patients submitted to aortic root replacement with valvar homografts.

In the day-to-day practice, our subjective impression is that patients with valvar homografts present a more favorable immediate postoperative evolution, with a better heart outflow and less necessity of inotropic drugs than patients submitted to conventional implant of valve prostheses. This is especially noticeable in patients with small aortic rings and/or left ventricle dysfunction, where the use of grafts with a more physiological hemodynamic function can have a great impact in reducing in-hospital death. For Blais et al. [14], the mortality rate for aortic

Table 4. Pre and post operative echocardiographic data

\begin{tabular}{llll}
\hline Data & Preoperative echo & Immediate postoperative echo & Late postoperative echo \\
\hline EF & $61.6 \pm 12.8(12-90)$ & $57.2 \pm 10.8(21-87)$ & $64.9 \pm 10.7(23-85)$ \\
LV Mass & $292 \pm 111(64.5-654)$ & $282.2 \pm 93.5(86.2-565.5)$ & $208.3 \pm 91.6(61.6-482.2)$ \\
Maximum Ao gradient & $56.3 \pm 35.1(5-130)$ & $11.3 \pm 6.5(3-50)$ & $14.5 \pm 8.4(3-47)$ \\
Medium Ao gradient & $36.5 \pm 22.6(2-84)$ & $6.4 \pm 4.1(2-22)$ & $7.6 \pm 5.9(2-35)$ \\
Septum & $14.5 \pm 2.6(7-22)$ & $13 \pm 2.1(8-19)$ & $12 \pm 2.3(6-20)$ \\
Posterior wall & $13.2 \pm 2.2(7-20)$ & $12.4 \pm 2.1(8-18)$ & $11 \pm 1.8(6-16)$ \\
AoI = moderate & 72 & 1 & 4
\end{tabular}


valve replacement in patients with a bad ventricle function is 11.4 times higher when the hemodynamic performance was unsatisfactory (patient-prosthesis mismatch).

O'Brien et al. [1] analyzed the long-term results of 1022 aortic homograft implants followed up over 29 years. Though the durability of cryopreserved grafts was better than fresh ones over 10 and 15 years of evolution, the primary structural function was similar in the groups over 20 postoperative years, demonstrating that tissue degeneration is an unavoidable phenomenon of homologous biological tissue. In this study, the factor that was most associated to tissue degeneration was the patient's age. The durability of grafts at 10 years of evolution is greater than $93 \%$ in almost all age ranges, but only $47 \%$ in under 20 year-olds. Other studies confirmed this observation. Yacoub et al. [15] reported their 14-year experience using "homovital" homografts and demonstrated that $89 \%$ were free from dysfunction at 10 years of evolution. According to these authors an estimated $73 \%$ would be free of dysfunction after 10 years of follow-up for a 15 -year-old patient at the time of implant and $97 \%$ for a 70 -year-old patient. Takkenberg et al. [4,5], using sophisticated statistical methodologies, calculated that the mean time for reoperation for primary structural dysfunction of homografts is 23 years in 65-yearold patients and only 12 years for 25 -year-old patients.

Our results confirm these observations, showing that the durability of valvar homografts is excellent until the $10^{\text {th }}$ year of evolution, with only one case of reoperation for primary structural dysfunction in a 13-year-old patient. By an extremely careful evaluation, using maximum instantaneous gradients of over $40 \mathrm{mmHg}$ or moderate valve insufficiency to identify cases of dysfunction, we observed that only $44 \%$ of the under 20 -year-old patients presented with normal functioning homografts after ten years of follow up. For this reason, in under 40-year-old patients, we perform the Ross operation $[1,10]$, reserving the use of homografts only for cases when the use of pulmonary autograft is not possible or in severe rheumatic mitralaortic patients, in which the damage of the mitral valve is extensive and with a more limited long-term prognosis. On the other hand, in over 40-year-old patients, the probability of homograft valve dysfunction is less than $5 \%$. This information is relevant specially among 40 to 60 -year-old patients in which the durability of conventional prostheses is still unsatisfactory $[16,17]$.

A promising alternative for young patients is that of decellularized homografts which, as they are less immunogenic, present with, at least theoretically, a lower tendency of calcification and possibility of being repopulated in vivo after the implant, which would result in a better resilience [18-20]. Based on our results with the use of decellularized homografts to reconstruct the right ventricle outflow tract in the Ross operation [21], we started, in some selected cases, to use them on the left side. The preliminary results according to echocardiographic and magnetic resonance follow-ups in these first eight cases are promising.

Lund et al. [2] analyzed 25 years of experience with valvar homografts and verified that, besides the patient's age, other variables significantly influence the results. The use of homografts with preserved cellular viability and the aortic root replacement technique increased both the durability of the graft and the long-term survival of patients. However, the factor that most influenced the durability of the graft was the donor's age, especially when they were older than 55 years old. In our series it was not possible to determine other predictive factors for tissue degeneration besides the patient's age, possibly because of the limited follow-up time and the low incidence of events. Moreover, all patients were operated on using total aortic root replacement and with presumably viable grafts.

The long-term survival was satisfactory even for elderly patients undergoing $\mathrm{CABG}$ or associated mitral valve repairs, which is probably due to the good hemodynamic performance seen with homografts that favors a reduction in the left ventricle mass. The observed gradients were invariably low even in patients with small aortic rings or those with big body surface areas. For the same reason, the improvement of the functional capacity in the postoperative period was also adequate, with the majority of patients presenting an optimum functional capacity $[22,23]$.

One of the advantages of valvar homografts is the low thrombogenicity, with a lower incidence of thromboembolic phenomena compared to conventional biological prosthesis $[1,2,4]$. Our linear incidence of $0.8 \%$ events/year confirms this, with seven out of the eight episodes occurring in male patients and over 65-year-olds. Although all events were attributed to the prostheses, it is known that ischemic or hemorrhagic strokes are more frequent in men in this age group.

Another favorable characteristic of valvar homografts are their resistance to infection $[1,2,6,11]$. In this series, $97 \%$ of the patients did not present with infections within the 10 first postoperative years and no patients operated on for bacterial endocarditis presented with further infections. Valvar homografts are especially useful in the reconstruction of infected aortic rings, facilitating the reestablishment of the ventriculo-arterial connection, the closure of fistulas and abscess repairs. For this reason, we also considered it to be the best graft for cases of bacterial endocarditis [24].

Technical difficulties are one of the greatest concerns of reoperations after aortic root replacement are necessary. Sundt et al. [25] reported their experience with 21 patients reoperated on after aortic homograft implants with aortic root replacement in which just one patient (5.4\%) died. The authors reported that calcification of the homograft wall was 
present in $52 \%$ of the cases with simply valve replacement possible inside the previously implanted homograft in many cases. Also in the experience of these authors, calcification of the graft wall, even when intense, was not invasive and the coronary ostia were preserved in all cases. However, other studies report high mortality rates ranging from 13 to $28 \%$ under the same circumstances [4,5].

Our experience is still limited to only three cases of reoperations, however the surgeries were technically more complex than the replacement of conventional dysfunctional prostheses. In reoperations due to tissue degeneration, there is significant calcification of the homograft artery wall, requiring complete resection and the implantation of a new valvar homograft. Moreover, in the proximal suture line, we could not find a division between the graft and the native aortic ring. The implant of the second graft was performed directly on the muscle of the left ventricle outflow tract. It probably occurred due to the routine use of Teflon or bovine pericardium strips to reinforce the proximal suture line during the first operation, which are no longer used. On the other hand, the coronary ostia were preserved and their dissection and re-implant were possible, highlighting the importance of the use of big aortic "buttons" in the original operation, thereby facilitating the release of coronary ostia in future reoperations. The other two patients presented intense inflammatory infiltration due to infectious processes, which caused difficulties during re-interventions.

\section{CONCLUSION}

Our 10-year experience with valvar homograft implants by aortic root replacement demonstrates that the operation can be performed with low immediate mortality rates, resulting in a good functional recovery of the patients and low incidences of long-term morbidity. The only factor correlated with primary tissue degeneration of the homografts was the age in under 20 -year-old patients. The results presented in this study indicate that homografts represent an excellent option for over 40 to 50 -yearold patients, especially in those who do not want to use anticoagulants or those where their use is contraindicated.

\section{REFERENCES}

1. OBrien MF, Harrocks S, Stafford EG, Gardner MA, Pohlner PG, Tesar PJ et al. The homograft aortic valve: a 29-year, $99.3 \%$ follow up of 1,022 valve replacements. J Heart Valve Dis. 2001;10(3):334-44.
2. Lund O, Chandrasekaran V, Grocott-Mason R, Elwidaa H, Mazhar R, Khaghani A et al. Primary aortic valve replacement with allografts over twenty-five years: valve-related and procedure-related determinants of outcome. J Thorac Cardiovasc Surg. 1999;117(1):77-91.

3. Langley SM, McGuirk SP, Chaudhry MA, Livesey SA, Ross JK, Monro JL. Twenty-year follow-up of aortic valve replacement with antibiotic sterilized homografts in 200 patients. Semin Thorac Cardiovasc Surg. 1999;11(4 Suppl 1):28-34.

4. Takkenberg JJ, Eijkemans MJ, van Herwerden LA, Steyerberg EW, Lane MM, Elkins RC et al. Prognosis after aortic root replacement with cryopreserved allografts in adults. Ann Thorac Surg. 2003;75(5):1482-9.

5. Takkenberg JJ, van Herwerden LA, Eijkemans MJ, Bekkers JA, Bogers AJ. Evolution of allograft aortic valve replacement over 13 years: results of 275 procedures. Eur J Cardiothorac Surg. 2002;21(4):683-91.

6. Doty JR, Salazar JD, Liddicoat JR, Flores JH, Doty DB. Aortic valve replacement with cryopreserved aortic allograft: ten-year experience. J Thorac Cardiovasc Surg. 1998;115(2):371-80.

7. Costa MTBA, Costa FDA, Nazareno LCF, Domachoski J, Peruzzo AM, Collatusso $\mathrm{C}$ et al. Análise das atividades dos oito anos iniciais do Banco de Valvas Cardíacas Humanas do Hospital de Caridade da Irmandade da Santa Casa de Misericórdia de Curitiba. Rev Bras Cir Cardiovasc. 2005;20(4):398-407.

8. Perry GJ, Helmcke F, Nanda NC, Byard C, Soto B. Evaluation of aortic insufficiency by Doppler color flow mapping. J Am Coll Cardiol. 1987;9(4):952- 9.

9. Edmunds LH Jr, Clark RE, Cohn LH, Grunkemeier GL, Miller DC, Weisel RD. Guidelines for reporting morbidity and mortality after cardiac valvular operations. Eur J Cardiothorac Surg. 1996;10(9):812-6.

10. Costa FDA, Pereira EWL, Barbosa LE, Filho HH, Collatusso C, Gomes CHG et al. Dez anos de experiência com a operação de Ross. Arq Bras Cardiol. (no prelo).

11. Doty DB. Replacement of the aortic valve with cryopreserved aortic allograft: the procedure of choice for young patients.J Card Surg. 1994;9(2 Suppl):192-5.

12. Pomerantzeff PMA, Brandão CMA, Cauduro P, Puig LB, Grinberg M, Tarasoutchi $\mathrm{F}$ et al. Biopróteses de pericárdio bovino Fisics-Incor: 15 anos. Rev Bras Cir Cardiovasc. 1997;12(4):359-66

13. Bacco FW, Sant`Anna JRM, Sant AAnna RT, Prates PR, Kalil RAK, Nesralla IA. Bioprótese valvar de pericárdio bovino St Jude Medical-Biocor: sobrevida tardia. Rev Bras Cir Cardiovasc. 2005;20(4):423-31. 
14. Blais C, Dumesnil JG, Baillot R, Simard S, Doyle D, Pibarot P. Impact of valve prosthesis-patient mismatch on shortterm mortality after aortic valve replacement. Circulation. 2003;108(8):983-8.

15. Yacoub M, Rasmi NR, Sundt TM, Lund O, Boyland E, Radley-Smith R et al. Fourteen-year experience with homovital homografts for aortic valve replacement. J Thorac Cardiovasc Surg. 1995;110(1):186-94.

16. Dagenais F, Cartier P, Voisine P, Desaulniers D, Perron J, Baillot $\mathrm{R}$ et al. Which biologic valve should we select for the 45- to 65-year-old age group requiring aortic valve replacement? J Thorac Cardiovasc Surg. 2005;129(5):10419.

17. Concha M, Aranda PJ, Casares J, Merino C, Alados P, Munoz I et al. Prospective evaluation of aortic valve replacement in young adults and middle-aged patients: mechanical prosthesis versus pulmonary autograft. J Heart Valve Dis. 2005;14(1):40-6.

18. Zehr KJ, Yagubyan M, Connolly HM, Nelson SM, Schaff HV. Aortic root replacement with a novel decellularized cryopreserved aortic homograft: postoperative immunoreactivity and early results. J Thorac Cardiovasc Surg. 2005;130(4):10105 .

19. Meyer SR, Nagendran J, Desai LS, Rayat GR, Churchill TA, Anderson $\mathrm{CC}$ et al. Decellularization reduces the immune response to aortic valve allografts in the rat. $\mathrm{J}$ Thorac Cardiovasc Surg. 2005;130(2):469-76.

20. Korossis SA, Wilcox HE, Watterson KG, Kearney JN, Ingham E, Fisher J. In-vitro assessment of the functional performance of the decellularized intact porcine aortic root. J Heart Valve Dis. 2005;14(3):408-22.
21. da Costa FD, Dohmen PM, Duarte D, von Glenn C, Lopes $\mathrm{SV}$, Filho $\mathrm{HH}$ et al. Immunological and echocardiographic evaluation of decellularized versus cryopreserved allografts during the Ross operation. Eur J Cardiothorac Surg. 2005;27(4):572-8.

22. Jin XY, Zhang ZM, Gibson DG, Yacoub MH, Pepper JR. Effects of valve substitute on changes in left ventricular function and hypertrophy after aortic valve replacement. Ann Thorac Surg. 1996;62(3):683-90.

23. Grocott-Mason RM, Lund O, Elwidaa H, Mazhar R, Chandrasakeran V, Mitchell AG et al. Long-term results after aortic valve replacement in patients with congestive heart failure. Homografts vs prosthetic valves. Eur Heart J. 2000;21(20):1698-707.

24. Imanaka K, Kyo S, Takamoto S, Motomura N, Shibusawa S, Ogiwara $\mathrm{M}$ et al. Aortic root replacement using an allograft for active infective endocarditis with periannular abscess: single center experience. J Cardiol. 2004;43(6):267-71.

25. Sundt TM 3rd, Rasmi N, Wong K, Radley-Smith R, Khaghani A, Yacoub MH. Reoperative aortic valve operation after homograft root replacement: surgical options and results. Ann Thorac Surg. 1995;60(2 Suppl):S95-100. 